\title{
COMPARISON AND CHARACTERIZATION OF GARLIC (Allium sativum L.) BULBS EXTRACTS AND THEIR EFFECT ON MORTALITY AND REPELLENCY OF Tetranychus urticae KOCH (ACARI: TETRANYCHIDAE)
}

\author{
Carlos Augusto Hincapié Ll. ${ }^{\text {* }}$, Gloria Eugenia López P. ${ }^{1}$, y Ricardo Torres Ch. ${ }^{2}$
}

\begin{abstract}
A B S T R A C T
Tetranychus urticae Koch is a pest that causes great economic losses because it attacks a wide range of host plants. Also, some populations have developed resistance against commercial acaricides. This work compares different extracts from garlic (Allium sativum $\mathrm{L}$.) bulbs measuring their toxicity and repellency effects on T. urticae. Extracts were obtained using as solvents $\mathrm{CO}_{2}$ in supercritical conditions (CSC), ethanol and petroleum ether using Soxhlet and soaking methods and soaking in water. The supercritical fluid extraction technique allows for obtaining extracts at low temperature using high pressures, avoiding compound degradation and making possible solvent separation by exposing the extract at room temperature. Mites were bred on bean plants (Phaseolus vulgaris L.) in a laboratory environment in Laureles Campus, Universidad Pontificia Bolivariana, Medellín, Colombia. Mortality was evaluated putting 10 mites in P. vulgaris $3 \mathrm{~cm}$ diameter leaf discs previously submersed in the extract. The lowest mean lethal concentrations $\left(\mathrm{LC}_{50}\right)$ were obtained with the $\mathrm{CSC}$ method $\left(8118.8,5410.5,2820.6 \mathrm{mg} \mathrm{kg}^{-1}\right.$ at 24,48 and 72 $\mathrm{h}$, respectively). Extracts were characterized using gas chromatography/mass spectrometry (GC/MS), finding vinyl dithiins (63.11\%), diallyl disulfide $(10.88 \%)$ and diallyl trisulfide $(10.4 \%)$ as the main compounds in the CSC extract. The main conclusion is that, in comparison with other techniques of extraction from garlic bulbs used in this study, supercritical fluids allow for obtaining extracts with a higher concentration of biologically active compounds against $T$. urticae.
\end{abstract}

Key words: two-spotted spider mite, plant extracts, miticidal effect, Liliaceae.

\section{INTRODUCTION}

The mite T. urticae belongs to the Aracnide Class, the Sub-Class Acari, Acariform Order and Tetranychidae Family. Traditionally this pest has been controlled using synthetic chemical acaricides with a level of residuality and permanence that constitute a barrier to the commercialization of agricultural products and cause detrimental effects to environment and human health. T. urticae is highly polyphagous species. To date 3877 host species have been reported around the world (Migeon and Dorkeld, 2007). Some populations of T. urticae submitted to the pressure of selection have developed resistance to the chemical products used for their control, such as fenbutatin oxide, hexythiazox and abamectin (Beers et al., 1998), bifenthrin, $\lambda$-cyalothrine and dimethoate (Yang et al., 2001), organophosphates (Stumpf et al., 2001; Anazawa et al., 2003), imidacloprid (James and Price, 2002), metil-paration and metomil (Tsagkarakou et al., 2002), tebufenpirad (Herron and Rophail, 2002) and clorfenapir and etoxazole (Uesugi et al., 2002). The resistance development makes it necessary to use greater quantities of products, more applications or more potent active ingredients. Within an Integrated Pest Management Program, botanic extracts with acaricide and/or repellent properties could be used, given that they have very short residual effects and can be compatible with biological control (Chiasson et al., 2004). Besides, these extracts degrade more rapidly than chemical products, which imply less possibility of finding them in plants, as well as in the soil, air and water, although they require a greater number of applications.

\footnotetext{
${ }^{1}$ Universidad Pontificia Bolivariana, Facultad de Ingeniería Agroindustrial, Grupo de Investigaciones Agroindustriales (GRAIN), A.A. 56006, Medellín, Colombia. E-mail: carlos.hincapie@upb.edu.co * Corresponding author.

${ }^{2}$ Universidad Nacional de Colombia, Magíster en Ciencias Químicas, Calle 59A No 63-20 Medellín, Colombia. E-mail: rtorres@epm.net.co The summary of this work was presented at the 33rd Congress of the Colombian Entomology Society (SOCOLEN) in Manizales, Colombia on 28 July 2006.

Received: 31 July 2007. Accepted: 15 November 2007.
} 
Some plants with acaricide and/or repellent effect against the mite are: A. sativum in an aqueous solution (Boyd and Alverson, 2000), Artemisia absinthium L. and Tanacetum vulgare L. (Chiasson et al., 2001), Piper longum L. (Park et al., 2002), Trichilia pallida Swartz and Melia azedarach L. (Castiglioni et al., 2002), Azadirachta indica A. Juss. (Castiglioni et al., 2002; Knapp and Kashenge, 2003; Chiasson et al., 2004); Satureja hortensis L., Ocimum basilicum L. and Thymus vulgaris L. (Aslan et al., 2004); Carum carvi L., Cymbopogon nardus (L.) Rendle, Eucalyptus citriodora Hook, Mentha pulegium L., Mentha piperita L., Mentha spicata L. (Choi et al., 2004), Chenopodium ambrosioides L. var. ambrosioides (Chiasson et al., 2004). Some organisms on which the insecticide or repellent action of garlic have been tested are: Acanthoscelides obtectus Say (RegnaultRoger and Hamraoui, 1993); Tribolium castaneum and Sitophilus zeamais (Ho et al., 1996; Chiam et al., 1999; Huang et al., 2000); Cydia pomonella L. (Landolt et al., 1999); Lipaphis erysimi Kaltenbach and Dysdercus cingulatus (Bandyopadhyay et al., 2001; Banerjee et al., 2004); Meloidogyne incognita (Chitwood, 2002); Reticulitermes santonensis and Reticulitermes grassei (Auger et al., 2004); and Attagenus unicolor japonicus (Han et al., 2006).

The traditional extraction methods can cause interactions between solvents and extracts, producing modifications in the original structure of the compounds. Besides, there is the risk of chemical residues that affects the ecological behavior of the extract. Extraction with supercritical fluids is a highly beneficial alternative to remove these problems. A supercritical fluid is any substance in conditions of pressure and temperature higher than its critical point; it is a quasi-state with intermediate properties between a liquid and a gas. Supercritical $\mathrm{CO}_{2}$ presents the best extraction conditions, with less interaction with the extract and low environmental impact (McClain, 2000).

The objective of this study was to compare the effects of different extract obtention methods from bulbs of A. sativum (supercritical $\mathrm{CO}_{2}$, water, ethanol and petroleum ether as solvents) on T. urticae. Each extract was characterized through CG/MS to identify the compounds and determine which have possibilities of biological action on mites.

\section{MATERIALS AND METHODS}

The study was done in 2006 at the Universidad Pontificia Bolivariana (Campus Laureles), Medellín (6¹4' N, $\left.75^{\circ} 35^{\prime} \mathrm{W}\right)$, Antioquia, Colombia, at an average altitude of 1450 m.a.s.l. and an average temperature of $22 \pm 1$ ${ }^{\circ} \mathrm{C}$ (IDEAM, 1999). The initial colony of mites was supplied by the Universidad Militar Nueva Granada, Cajicá Campus, Cundinamarca, Colombia. To maintain the colony and carry out the tests, bean plants $\mathrm{cv}$. Cargamanto, were seeded under laboratory conditions, so that germination and growth occurred in isolation. A tray was seeded weekly with approximately 12 bean seeds. When the plants were 4 weeks old, they were inoculated with leaves infested with mites. The plants were replaced every 4 weeks. The plants were irrigated daily and organic fertilizer was applied at seeding. Pest control was done manually in order to not use synthetic chemical products and thus avoid introducing error factors to the experiment.

Garlic bulbs from a cultivar known as "China white" were obtained in the local market, an option that has been taken by other researchers (Kuo and Ho, 1992; Calvey et al., 1994; Abu-Lafi et al., 2004; Kimbaris et al., 2006; Han et al., 2006). Subsequently, the bulbs were selected, cleaned, cut and mashed manually in the laboratory. The product obtained was used for the extractions. For the extraction with supercritical $\mathrm{CO}_{2}$ the gas (UN 2817, Agafano, Medellín, Colombia) was used as the solvent under supercritical conditions in an extractor (SFE1000, Thar Technologies, Pittsburgh, USA) located in the private company Colflavor S.A., Envigado, Antioquia. The temperature in the extractor was $40{ }^{\circ} \mathrm{C}$ and the pressure and $\mathrm{CO}_{2}$ flow were 25.33 $\mathrm{MPa}$ and $30 \mathrm{~g} \mathrm{~min}^{-1}$, respectively (Ryback et al., 2004). The extraction time was $1.5 \mathrm{~h}$. For extraction using the Soxhlet method, $100 \mathrm{~g}$ of sample was used, and petroleum ether 35-60 and ethanol at 99.7\% were used as solvents, for $8 \mathrm{~h}$. For soaking at room temperature, $100 \mathrm{~g}$ of sample in a hermetically sealed container was submitted to agitation for $24 \mathrm{~h}$, using the same solvents as used with Soxhlet. Finally, the extractions were filtered and the solvents separated at low temperature in a rotary evaporator (Waterbath-B-480, Büchi Labortechnik AG, Flawil, Switzerland). Soaking was also carried out in water. Unlike the previously described methods, in the latter case, the concentration was determined making a mass balance. To prepare each treatment, the solvents were removed exhaustively to avoid their incidence in the tests. The extracts prepared were: supercritical $\mathrm{CO}_{2}$ (CSC), soaking with petroleum ether (MEP), Soxhlet with ethanol (SAE), Soxhlet with petroleum ether (SEP), soaking with ethanol (MAE), and soaking with water (MA). Before use the extracts were stored in a refrigerator in hermetically sealed amber-colored 
containers and injected with highly purified nitrogen gas (Agafano, Medellín, Colombia).

To determine mortality with CSC extracts, concentration of 2500, 5000 and $10000 \mathrm{mg} \mathrm{kg}^{-1}$ were prepared; as well, concentrations of $10000,25000,50000,100000$, 150000 and $200000 \mathrm{mg} \mathrm{kg}^{-1}$ were prepared for the MEP, MAE, SEP and SAE extracts. Concentrations of $68500,45700,22800,11400$ and $4600 \mathrm{mg} \mathrm{kg}^{-1}$ were prepared for the MA extract. The extract was solved in distilled water. Owing to conditions inherent to the soaking process and the concentration of the solvent, extracts of over $76800 \mathrm{mg} \mathrm{kg}^{-1}$ were not obtained. Thus 34 treatments were obtained, with three replicates of each one. Concentrations of 1000,2000 and 5000 $\mathrm{mg} \mathrm{kg}{ }^{-1}$ were used with all the extracts for repellence tests. A completely random design was used, with 24 treatments and three replicates of each, 18 treatments (six extracts with three concentrations), the absolute control (distilled water) and the positive control, abamectina $75 \mathrm{mg} \mathrm{kg}^{-1}$ (CATOMBE 1.8 EC, Químicos Oma, Colombia). The concentrations were determined after preliminary tests to establish the ranges of action on the mites.

For the mortality tests eight 3 -cm diameter disks of young leaves of bean were immersed in each treatment, and then deposited on Petri plates with filter paper moistened with distilled water. After drying, 10 adult mites were placed in each disk and were covered. Mortality was evaluated at 24, 48 and $72 \mathrm{~h}$ and a mite was considered dead when it presented no movement after being poked by a brush bristle (Chiasson et al., 2001; 2004; Castiglioni et al., 2002; Kwon and Ahn, 2002a; 2002b; Kim et al., 2003; 2004a; 2004b; Choi et al., 2004). The percentage of mortality was calculated considering the data obtained from the absolute control and the treatments corrected with Abbott's formula (1925).

For the repellence bio-tests the same procedure was used as for the mortality tests, except that over half of each $3 \mathrm{~cm}$ disk a $14 \mathrm{~mm}$ leaf disk without treatment was placed, and 10 adult mites were placed on this smaller disk. The mites that remained there were counted at $0.25 ; 0.5 ; 0.75 ; 1 ; 2 ; 3$ and $4 \mathrm{~h}$ (Boyd and Alverson, 2000). The information gathered in the repellence tests was analyzed with repeated measurement using the PROC MIX module from the SAS program (SAS Institute, 1999), with which the variance analysis was carried out. Significant differences were identified with the Minimal Significant Differences test. The mean lethal concentration $\left(\mathrm{LC}_{50}\right)$ was determined using the
PROBIT module of the SAS program, with the probit method proposed by Bliss (1934) and developed by Finney (1947).

The extracts were re-dissolved into their respective solvents for the chromatographic analysis. The CSC extract was dissolved in dicloromethane (Calvey et al., 1994). For the MA extract, an equal quantity of dicloromethane was added in order to extract the sulphurated compounds of low to medium polarity present in this extract (Kuo and Ho, 1992). The solvents were eliminated before using the mass detector. The characterization was done by CG/MS (6890N Network GC System, Mass selective detector 5973 Network and Injector 7683 Series; Agilent Technologies, Palo Alto, California, USA) in the laboratory of instrumental analysis of the Universidad Nacional de Colombia, Medellín Campus. An HP 5 fused silica capillary column was used $(30 \mathrm{~m} \times 0,25 \mathrm{~mm}$, film thickness of 0.25 um) (Abu-Lafi et al., 2004; Kimbaris et al., 2006). For detection it was used ionization energy of $70 \mathrm{eV}$. The temperatures of the injector and the detector were fixed at 220 and $290^{\circ} \mathrm{C}$, respectively. An helium flow

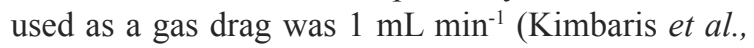
2006). The oven was programmed to begin at $40^{\circ} \mathrm{C}$ for 2 min, increasing $2^{\circ} \mathrm{C}$ every 2 min (Block, 1992) until $300{ }^{\circ} \mathrm{C}$, which was maintained for $20 \mathrm{~min}$ (Abu-Lafi et al., 2004). The compounds were identified with the NIST 98 library incorporated into the equipment.

\section{RESULTS AND DISCUSSION}

\section{Mortality}

The CSC extract was the most toxic, followed by MEP (Table 1). Mortalities of less than $40 \%$ were obtained with MA in the majority of the cases, because of which it registered $\mathrm{LC}_{30}$; it should be noted that the concentration of the extract could not be increased because it is not obtained in pure form but diluted in water, at a concentration that does not exceed on average 76800 $\mathrm{mg} \mathrm{kg}{ }^{-1}$. The extracts that showed greater mortality were obtained under conditions of low temperatures, which suggests that these conditions favor obtaining compounds with greater acaricide effect than those that can be obtained at higher temperatures. The solvent polarity also appears to influence the results, given that the $\mathrm{CO}_{2}$ and petroleum ether are non-polar solvents. These two extracts have similar percentages of diallyl sulfide (CSC: $23.058 \%$ and MEP: $24.842 \%$ ) and disulfide (CSC: $12.537 \%$ and MEP: $14.798 \%$ ), but present major differences in vinyl dithiins (CSC: $63.11 \%$ and MEP: $10.173 \%$ ). With regard to the disulfides, the two 
Table 1. Mean lethal concentration $\left(\mathrm{LC}_{50}\right)$ on Tetranychus urticae from garlic bulb extract in each evaluated time.

\begin{tabular}{|c|c|c|c|c|c|c|}
\hline \multirow{3}{*}{$\begin{array}{l}\text { Extraction } \\
\text { method }\end{array}$} & \multicolumn{6}{|c|}{ Time } \\
\hline & \multicolumn{2}{|r|}{$24 \mathrm{~h}$} & \multicolumn{2}{|r|}{$48 \mathrm{~h}$} & \multicolumn{2}{|r|}{$72 \mathrm{~h}$} \\
\hline & $C L_{50}$ & CI a $95 \%$ & $\mathrm{LC}_{50}$ & CI a $95 \%$ & $\mathbf{L C}_{50}$ & CI a $95 \%$ \\
\hline & $\mathrm{mg} \mathrm{kg}^{-1}$ & & $\mathrm{mg} \mathrm{kg}^{-1}$ & & $\mathrm{mg} \mathrm{kg}^{-1}$ & \\
\hline $\mathrm{CSC}$ & 8118.8 & (5 815.1-17 868.3) & 5410.5 & (3 715.3-8 514.3) & 2820.6 & $(282.1-4425.6)$ \\
\hline MEP & 26794.6 & (17 087.9-37 012.8) & 17179.5 & (7 978.6-26 683.7) & 17665.0 & (9 969.7-25 480.9) \\
\hline SAE & 117838.4 & (87 073.3-177 283.5) & 82080.6 & (53 166.7-142 646.5) & 47993.6 & $(3612.5-195$ 831.5) \\
\hline SEP & 208759.5 & $(--)$ & 209557.4 & $(--)$ & 97872.9 & $(--)$ \\
\hline MAE & 231321.0 & (140 026.2-669 253.3) & 176537.4 & (102 478.7-586 922.1) & 71134.6 & $(--)$ \\
\hline $\mathrm{MA}^{\mathrm{a}}$ & 67296.9 & $(26566.8-103380)$ & 55912.5 & $(--)$ & 12130.8 & $(179.6-27863.4)$ \\
\hline
\end{tabular}

${ }^{\text {a }} \mathrm{CL}_{30}$ is registered because $50 \%$ mortality was not reached in any of the tests, nor $40 \%$ in some.

CI: confidence interval; (--): because of the behavior of the data, the probit did not provide a confidence interval.

CSC: supercritical $\mathrm{CO}_{2}$; MEP: soaking with petroleum ether; SAE: Soxhlet with ethanol; SEP: Soxhlet with petroleum ether; MAE: soaking with ethanol; MA: soaking with water.

extracts have higher percentages than the other extracts (Table 2 and 3). With STATGRAPHICS PLUS V.5.0 (StatPoint Inc., 1994) the correlation was determined between the relative percentage of disulfides and $\mathrm{LC}_{50}$ at $24\left(r^{2}=79.4192\right.$ and $\left.\mathrm{p}=0.0424\right), 48\left(\mathrm{r}^{2}=73.9096\right.$ and $\mathrm{p}=0.0617)$ and $72 \mathrm{~h}\left(\mathrm{r}^{2}=75.3829\right.$ and $\left.\mathrm{p}=0.0563\right)$. Aqueous soaking was not considered for this analysis because was not obtained $\mathrm{LC}_{50}$ with it.

\section{Repellence}

Through the comparison of covariance structures, using goodness of fit tests or information criteria that are generated for each structure, the type of behavior of the data was identified, and it was found that it had a compound symmetrical structure. The Schwartz's Bayesian information criterion (BIC) (Correa, 2004) was used because it was the most accurate. Subsequently, a variance analysis was carried out, finding significant differences between the means of the treatments and significance in the first order interaction between the treatments and the time $(\mathrm{F}=1.31 ; \mathrm{df}=114 ; \mathrm{P}=0.0427)$. As interaction was significant, it was not adequate to do individual analysis of main effects (Correa, 2004). The most repellent extract was that obtained by soaking with petroleum ether (MEP) (Table 2).

The compounds found in greater quantity in the MEP extract are methyl 2-propanol disulfide, dimethyl trisulfide, diallyl disulfide, 2-ethylidene[1,3]dithiane, and di-2-propenyl trisulfide and 3-vinyl-1,2-dithiociclohex5 -ene (Table 3). These could be responsible for the repellent effect owing to their volatility and strong odor. The MA extract has a low percentage of such compounds and the CSC has only $1.657 \%$ methyl 2-propanol disulfide and trisulfide, but an appreciable concentration of diallyl disulfide (10.88\%). These two extracts were the least repellent. These results are better than those obtained by Boyd and Alverson (2000), who used concentrations of 100, 50, 20 and 10\% of Garlic Barrier AG (a commercial insect repellent described as aqueous garlic [Garlic Barrier, 1999]), an aqueous garlic juice produced in the laboratory and a mixture of mineral oil and garlic powder. Significant repellence was observed with the commercial product at $100 \%$ in all the times, and for 30 and $45 \mathrm{~min}$ at $50 \%$. This suggests that this type of extract should be used in almost pure form in order to have any effect.

From the statistical point of view, the use of any extract as a repellent of $T$. urticae in the concentrations used in this study is the same (with the exception of the aqueous and the CSC extracts at 1000 and $2000 \mathrm{mg} \mathrm{kg}^{-1}$ ). As well, it was found that there is a statistically significant relationship between the percentage of acyclic sulphurated compounds and maximum repellence obtained at $4 \mathrm{~h}$ $\left(r^{2}=87.2046\right.$ and $\left.p=0.0064\right)$. This correlation suggests that acyclic compounds present in the extracts are, in great part, responsible for the repellence of mites. To define a possible commercial product or to carry out further tests it will be necessary to analyze factors such as the performance of the extraction, solvent cost, saving of energy and processing time, among others.

\section{Compounds identified and their influence on mortality and repellence}

A number of important sulphurated compounds were identified in the majority of the extracts between 10 and 63 min (retention time) (Figures 1 and 2). After 
Table 2. Repellence percentages on Tetranychus urticae of each garlic bulb extract in each evaluated time.

\begin{tabular}{|c|c|c|c|c|c|c|c|c|}
\hline \multirow{2}{*}{$\begin{array}{c}\text { Extraction } \\
\text { method }\end{array}$} & \multirow{2}{*}{ Concent. } & \multicolumn{7}{|c|}{ Repellence for each observation time (h) } \\
\hline & & 0.25 & 0.5 & 0.75 & 1 & 2 & 3 & 4 \\
\hline \multirow{4}{*}{$\mathrm{CSC}$} & $\mathrm{mg} \mathrm{kg}^{-1}$ & & & & $-\%$ & & & \\
\hline & 1000 & $36.67 \mathrm{a}$ & $30.00 \mathrm{a}$ & $26.67 \mathrm{a}$ & $26.67 \mathrm{a}$ & $30.00 \mathrm{a}$ & $23.33 a$ & $16.67 \mathrm{a}$ \\
\hline & 2000 & $36.67 \mathrm{a}$ & $33.33 \mathrm{a}$ & $36.67 \mathrm{a}$ & $33.33 \mathrm{a}$ & $30.00 \mathrm{a}$ & $26.67 \mathrm{a}$ & $26.67 \mathrm{ab}$ \\
\hline & 5000 & $83.33 \mathrm{c}$ & $70.00 \mathrm{~cd}$ & $63.33 \mathrm{bc}$ & $66.67 \mathrm{bcde}$ & $66.67 \mathrm{bcdef}$ & $66.67 \mathrm{cdef}$ & $63.33 \mathrm{def}$ \\
\hline \multirow{3}{*}{ MEP } & 1000 & $90.00 \mathrm{c}$ & $90.00 \mathrm{de}$ & $90.00 \mathrm{cde}$ & $90.00 \mathrm{ef}$ & $86.70 \mathrm{ef}$ & $90.00 \mathrm{f}$ & 90.00 fgh \\
\hline & 2000 & $100.00 \mathrm{c}$ & $100.00 \mathrm{e}$ & $100.00 \mathrm{e}$ & $100.00 \mathrm{f}$ & $93.30 \mathrm{f}$ & $93.30 \mathrm{f}$ & $96.70 \mathrm{~h}$ \\
\hline & 5000 & $96.70 \mathrm{c}$ & $93.30 \mathrm{de}$ & 90.00 cde & $90.00 \mathrm{ef}$ & $86.70 \mathrm{ef}$ & $90.00 \mathrm{f}$ & 83.30efgh \\
\hline \multirow{3}{*}{ SAE } & 1000 & $96.70 \mathrm{c}$ & $93.30 \mathrm{de}$ & $96.70 \mathrm{de}$ & 93.30ef & $93.30 \mathrm{f}$ & 93.30f & $90.00 \mathrm{fgh}$ \\
\hline & 2000 & $93.30 \mathrm{c}$ & 86.70de & $90.00 \mathrm{cde}$ & 76.70cdef & 66.70bcdef & 70.00def & 70.00defgh \\
\hline & 5000 & $86.70 \mathrm{c}$ & $76.70 \mathrm{de}$ & $86.70 \mathrm{cde}$ & $86.70 \mathrm{def}$ & $83.30 \mathrm{ef}$ & $86.70 \mathrm{ef}$ & 83.30efgh \\
\hline \multirow{3}{*}{ SEP } & 1000 & $83.30 c$ & 76.70de & 76.70bcde & 76.70cdef & 76.70def & 76.70def & 76.70defgh \\
\hline & 2000 & $96.70 \mathrm{c}$ & $90.00 \mathrm{de}$ & 90.00 cde & $93.30 \mathrm{ef}$ & $83.30 \mathrm{ef}$ & 76.70def & $80.00 \mathrm{efgh}$ \\
\hline & 5000 & $93.30 \mathrm{c}$ & $93.30 \mathrm{de}$ & $93.30 \mathrm{de}$ & $90.00 \mathrm{ef}$ & $93.30 \mathrm{f}$ & $90.00 \mathrm{f}$ & $93.30 \mathrm{gh}$ \\
\hline \multirow{3}{*}{ MAE } & 1000 & $83.30 c$ & $83.30 \mathrm{de}$ & $83.30 \mathrm{cde}$ & $80.00 \mathrm{cdef}$ & $80.00 \mathrm{ef}$ & $80.00 \mathrm{ef}$ & 73.30defgh \\
\hline & 2000 & $83.30 \mathrm{c}$ & $80.00 \mathrm{de}$ & $76.70 \mathrm{bcde}$ & $86.70 \mathrm{def}$ & 73.30cdef & 70.00def & 73.30defgh \\
\hline & 5000 & $80.00 \mathrm{c}$ & $80.00 \mathrm{de}$ & $76.70 \mathrm{bcde}$ & $76.70 \mathrm{cdef}$ & $70.00 \mathrm{cdef}$ & 73.30def & 63.30def \\
\hline \multirow{3}{*}{ MA } & 1000 & $43.30 \mathrm{a}$ & $40.00 \mathrm{ab}$ & $0.00 \mathrm{a}$ & $40.00 \mathrm{ab}$ & $40.00 \mathrm{ab}$ & $40.00 \mathrm{abc}$ & $33.30 \mathrm{abc}$ \\
\hline & 2000 & $53.30 \mathrm{ab}$ & $53.30 \mathrm{abc}$ & $53.30 \mathrm{ab}$ & $53.30 \mathrm{abc}$ & $50.00 \mathrm{abcd}$ & $50.00 \mathrm{abcd}$ & $50.00 \mathrm{bcd}$ \\
\hline & 5000 & $76.70 \mathrm{bc}$ & $70.00 \mathrm{~cd}$ & $70.00 \mathrm{bcd}$ & $70.00 \mathrm{cde}$ & 63.30abcde & $60.00 \mathrm{bcde}$ & $56.70 \mathrm{cde}$ \\
\hline $\begin{array}{l}\text { Absolute } \\
\text { control }\end{array}$ & 0 & $73.30 \mathrm{bc}$ & $66.70 \mathrm{bcd}$ & $63.30 \mathrm{abc}$ & $53.30 \mathrm{bcd}$ & $46.70 \mathrm{abc}$ & $33.30 \mathrm{ab}$ & $23.30 \mathrm{ab}$ \\
\hline $\begin{array}{c}\text { Positive } \\
\text { control } \\
\text { (abamectin) }\end{array}$ & 750 & $86.67 \mathrm{c}$ & $73.33 \mathrm{cde}$ & $70.00 \mathrm{bcd}$ & 70.00 cde & $66.67 \mathrm{bcdef}$ & $66.67 \mathrm{cdef}$ & 66.67defg \\
\hline
\end{tabular}

Data followed by the same letter does not have a significant difference according to the minimum significant difference test $(\mathrm{P}<0.05)$.

CSC: supercritical $\mathrm{CO}_{2}$; MEP: soaking with petroleum ether; SAE: Soxhlet with ethanol; SEP: Soxhlet with petroleum ether; MAE: soaking with ethanol; MA: soaking with water.

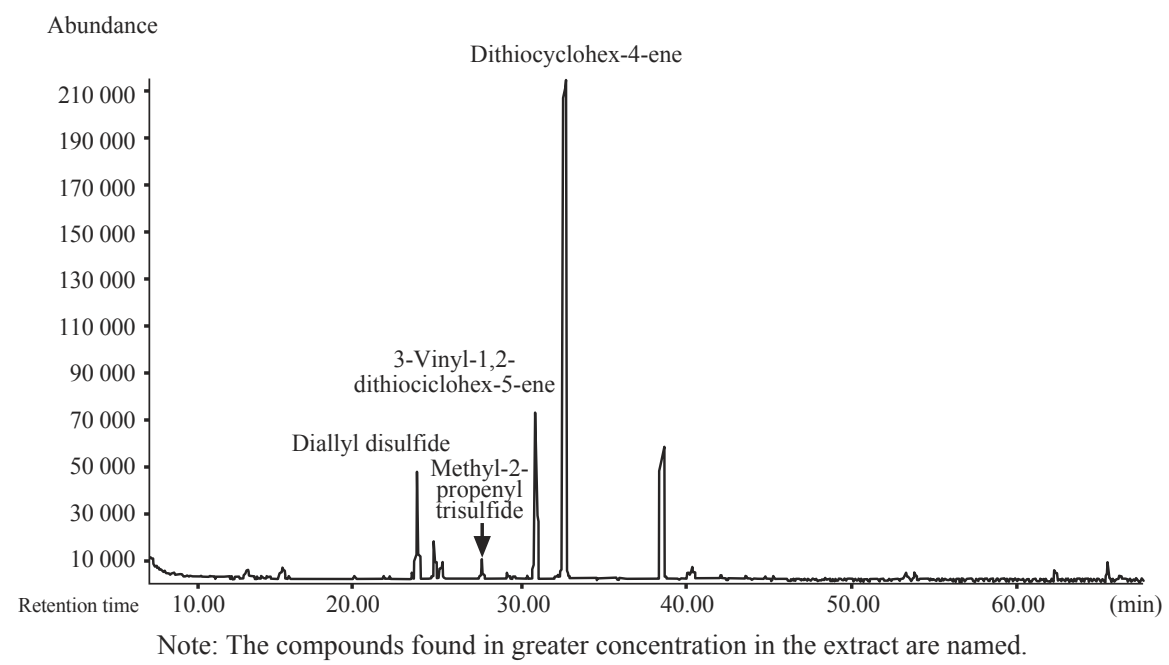

Figure 1. Chromatogram with peaks that indicate identified compounds from supercritical $\mathrm{CO}_{2}$ extract. 


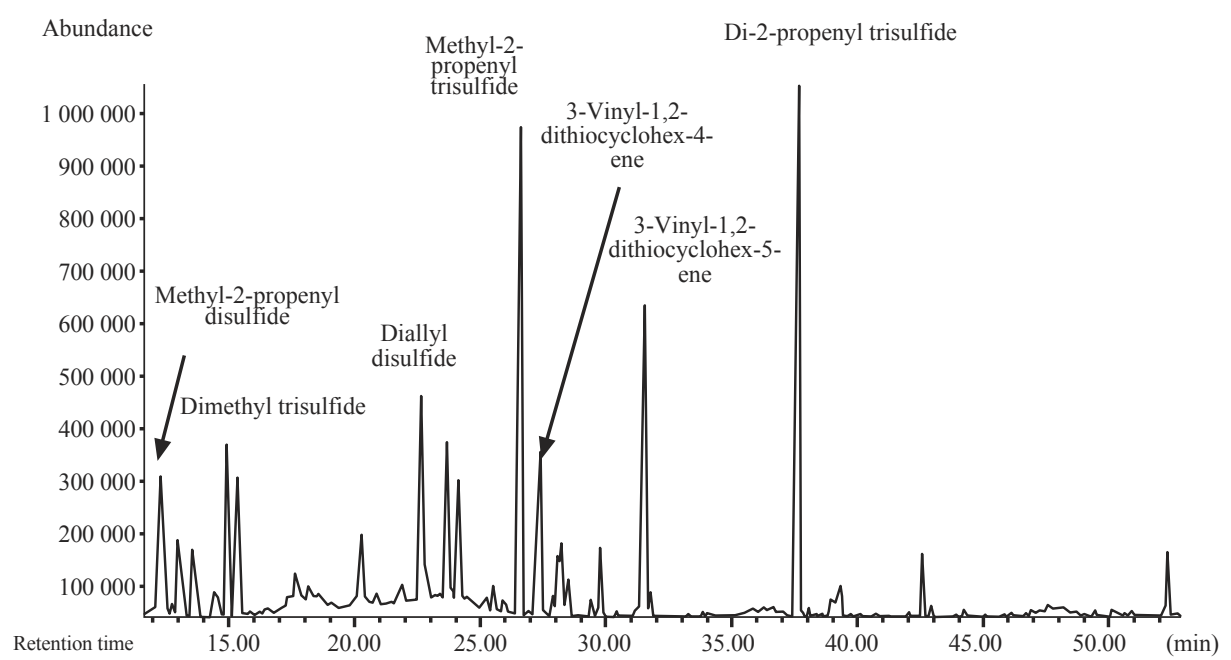

Note: The compounds found in greater concentration in the extract are named.

Figure 2. Chromatogram with peaks that indicate identified compounds from petroleum ether soaking extract.

Table 3. Comparison between most found compounds in each extract.

\begin{tabular}{|c|c|c|c|c|c|c|}
\hline \multirow{2}{*}{ Name of the compound } & \multicolumn{6}{|c|}{ Peak area with each extraction method } \\
\hline & CSC & MEP & SAE & SEP & MAE & MA \\
\hline Methyl 2-propanol disulfide & 1.66 & 8.20 & $\mathrm{Nd}$ & 1.18 & 2.48 & 0.92 \\
\hline Dimethyl trisulfide & $\mathrm{Nd}$ & 5.08 & 1.15 & 7.89 & 2.51 & 0.87 \\
\hline Diallyl disulfide & 10.88 & 6.60 & 7.25 & 5.06 & 5.01 & 2.23 \\
\hline 2-Ethylidene[1,3]ditiane & $\mathrm{Nd}$ & 5.09 & $\mathrm{Nd}$ & 6.91 & 2.33 & 0.41 \\
\hline Methyl 2-propanol trisulfide & 1.68 & 14.57 & 9.48 & 16.75 & 6.02 & 3.66 \\
\hline 3-Vinyl-1,2-ditiocyclohex-4-ene & 47.78 & 1.67 & $\mathrm{Nd}$ & 8.19 & 8.39 & 10.80 \\
\hline 3-Vinyl-1,2-ditiocyclohex-5-ene & 15.33 & 8.50 & $\mathrm{Nd}$ & $\mathrm{Nd}$ & 6.80 & 22.72 \\
\hline Unknown $^{\mathrm{a}}$ & $\mathrm{Nd}$ & $\mathrm{Nd}$ & 32.16 & $\mathrm{Nd}$ & $\mathrm{Nd}$ & $\mathrm{Nd}$ \\
\hline Di-2-propenyl trisulfide (isomer) ${ }^{\mathrm{b}}$ & $\mathrm{Nd}$ & $\mathrm{Nd}$ & $\mathrm{Nd}$ & $\mathrm{Nd}$ & 12.50 & $\mathrm{Nd}$ \\
\hline Di-2-propenyl trisulfide & 10.40 & 16.76 & 19.82 & 16.39 & 11.71 & 5.96 \\
\hline Diallyl tetrasulfide & 1.78 & 1.48 & 4.83 & 0.87 & 1.92 & 0.95 \\
\hline Benzeneacetaldehyde & $\mathrm{Nd}$ & 2.89 & 4.70 & 2.80 & 1.29 & $\mathrm{Nd}$ \\
\hline Total disulfide & 12.54 & 14.80 & 7.25 & 6.25 & 7.49 & 3.15 \\
\hline Total trisulfide ${ }^{\mathrm{d}}$ & 12.08 & 36.40 & 30.45 & 41.03 & 32.74 & 10.50 \\
\hline Total vinyl dithiins ${ }^{\mathrm{e}}$ & 63.11 & 10.17 & $\mathrm{Nd}$ & 8.19 & 15.19 & 33.52 \\
\hline Total diallyl sulfide ${ }^{f}$ & 23.06 & 24.84 & 31.91 & 22.33 & 31.14 & 9.14 \\
\hline Total acyclic sulfides ${ }^{\mathrm{g}}$ & 26.40 & 52.68 & 42.53 & 48.15 & 29.65 & 14.60 \\
\hline
\end{tabular}

CSC: supercritical $\mathrm{CO}_{2}$; MEP: soaking with petroleum ether; SAE: Soxhlet with ethanol; SEP: Soxhlet with petroleum ether; MAE: soaking with ethanol; MA: soaking with water.

Nd: not detected by the equipment.

${ }^{a}$ Considered unknown because of the low probability found in the mass spectrometer; ${ }^{b}$ the compound di-2-propenyl trisulfide was identified in two different retention times in the MAE extract, one of these with a probability of $95.5 \%$ and the other with $98.8 \%$; it is assumed that this last as indicated compound and the first as an isomer given the very high probability; ${ }^{\mathrm{c}}$ Methyl 2-propanol disulfide and diallyl disulfide; ${ }^{\mathrm{d}}$ Dimetil trisulfide, methyl 2-propanol trisulfide and di-2-propenyl trisulfide; ${ }^{\mathrm{e}}$ 3-vinyl-1,2-ditiocyclohex-4-ene y 3-vinyl-1,2-ditiocyclohex5-ene; ${ }^{\mathrm{f}}$ Diallyl disulfide, di-2-propenyl trisulfide and diallyl tetrasulfide; ${ }^{\mathrm{g}}$ Diallyl tetrasulfide, di-2-propenyl trisulfide, methyl 2-propanol trisulfide, diallyl disulfide, dimethyl trisulfide, and methyl 2-propanol disulfide. 
this time different compounds were obtained that were not of interest for the research, mainly long chain hydrocarbons. The main compounds of CSC extract are 2 vinyl dithiins, which together represent $63.11 \%$ (Table 3). These compounds were also identified by Yu et al. (1989), Abu-Lafi et al. (2004) and Calvo-Gomez et al. (2004). Block (1992) proposed that the conversion of allicin in vinyl dithiins, as well as in other compounds, is evident with chromatographic analysis under certain conditions. To verify that the transformation of allicin does not occur during the extractive process, Abu-Lafi et al. (2004) used cryogenic extraction techniques and CG/MS and high performance liquid chromatography (HPLC) as analysis methods and still obtained allicin as the predominant compound in all the extracts analyzed, concluding that these compounds are the major sulphurated components of fresh garlic and that during some processes (vapor distillation, frying or bleaching) they decompose and form other compounds. In the extracts obtained with petroleum ether higher relative percentage of trisulfides were found (MEP: $36.407 \%$ and SEP: $41.03 \%$ ) and, in those obtained with ethylic alcohol, somewhat lower percentages were obtained (MAE: $32.743 \%$ and SAE: $30.446 \%$ ); in contrast, in those obtained with water and supercritical $\mathrm{CO}_{2}$ the trisulfides percentages were substantially lower (CSC: $12.08 \%$ and MA: $10.50 \%$ ) (Table 3). Figure 3 shows the structures of the main compounds found.

Interaction with the solvents seems to be a very influential factor in the formation of compounds within the extracts. Notable is the case of extracts obtained using petroleum ether and ethylic alcohol, whose relative concentrations of dimethyl trisulfide range from $30.47 \%$ to $41.03 \%$, while that in water and $\mathrm{CO}_{2}$ reached $12.08 \%$ as a maximum. Cyclic compounds predominate in the latter extracts. The permanence time of $\mathrm{CO}_{2}$ with the extract was the same as the extraction process $(1.5 \mathrm{~h})$, consequently it vaporized at room temperature, while with the other solvents the permanence time was $8 \mathrm{~h}$ (Soxhlet) and $24 \mathrm{~h}$ (maceration), plus the lapse between extraction and separation of the solvent. Iberl et al. (1990) propose that vinyl dithiins are not directly produced by catalyzed reactions by allinase, but rather by the allicin decomposition produced in solvents less polar than water.

Temperature also appears to influence the type of compounds found in the different extracts. Vinyl dithiins were found mainly in the extracts obtained at low temperatures (except for $8.19 \%$ found in one of them in the SEP extracts at approximately $60^{\circ} \mathrm{C}$ ). Nevertheless, a simple linear correlation between process temperatures and vinyl dithiins percentage in each extract showed that there is no statistically significant relationship among them $\left(r^{2}=11.7894 \%\right.$ and $\left.p=0.5052\right)$. However, analyzing only the information of the extracts obtained with ethylic alcohol and petroleum ether it was established that there is a statistically significant relationship between temperature and vinyl dithiins percentage $\left(r^{2}=73.232 \%\right.$ and $\left.p=0.1212\right)$. It is very probable that the greater toxicity of CSC extract is due to the high percentage of vinyl dithiins compared to the other extracts. As well, it was found that the CSC

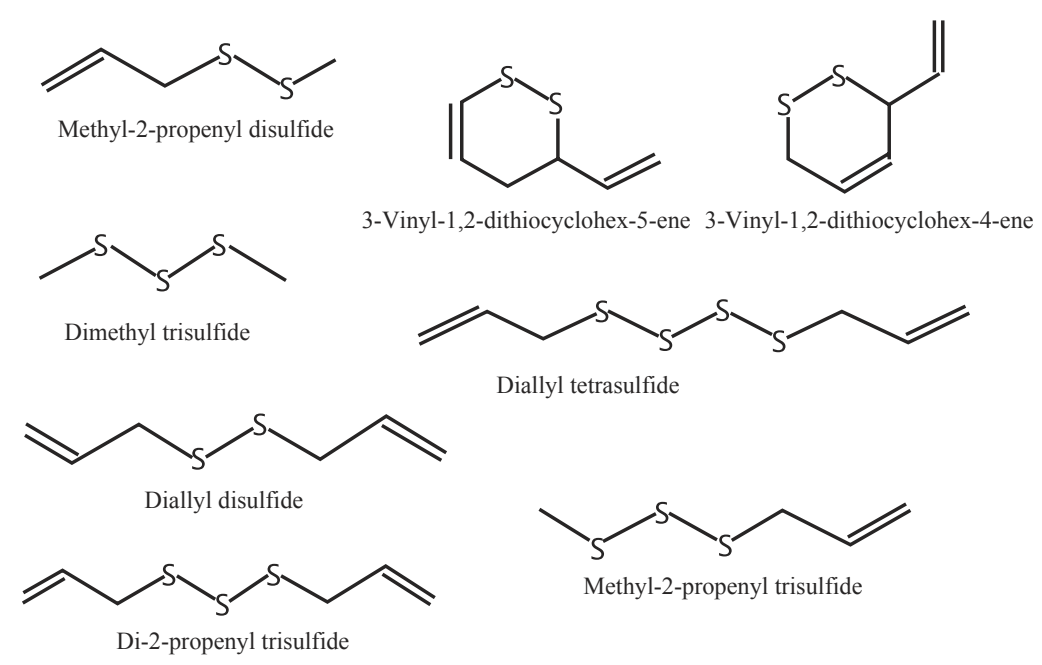

Figure 3. Structures of the main compounds in the extracts.

Source: NIST98 database (National Institute for Standards and Technology, 1998). 
extracts had very small quantities of other sulphurated compounds others than vinyl dithiins, di-2-propenyl trisulfide, methyl 2-propanol disulfide and diallyl disulfide and tetrasulfide, resulting in a relatively clean product. These observations are in accordance with Calvey et al. (1998) and Ryback et al. (2004). The aqueous extract also has a relatively important percentage of vinyl dithiins $(33.52 \%)$ probably because dicloromethane was used to obtain the extract for chromatographic analysis, a solvent that was also used to dissolve the extract obtained by supercritical $\mathrm{CO}_{2}$ to carry out the same operations.

Another important compound in the CSC extract was diallyl disulfide (DADS), with the greatest percentage of all the extracts (10.88\%). Auger et al. (2004) found that the $\mathrm{LC}_{50}$ of this pure substance against $R$. santonensis and $R$. grasse $i$ was 3400 and $2500 \mathrm{mg} \mathrm{kg}^{-1}$, respectively; thus suggesting that DADS can also be responsible for acaricide activity. In this same study dimethyl disulfide showed $\mathrm{L} \mathrm{LC}_{50}$ against these two termites of 150 and 100 $\mathrm{mg} \mathrm{kg}^{-1}$, respectively; this compound was not found in any extraction in the present research, perhaps because of its high volatility, its capture not being possible under the conditions used in this study.

\section{CONCLUSIONS}

The garlic bulbs extract obtained with supercritical $\mathrm{CO}_{2}$ showed the lowest $\mathrm{CL}_{50}$ against $T$. urticae under laboratory conditions in comparison to the other extracts. The high concentration of cyclic compound could be the explanation for this effect.

There are no significant statistical differences between most of extraction methods in terms of repellence against $T$. urticae with the concentrations analyzed in this study (except for the aqueous extract and the CSC at 1000 and $2000 \mathrm{mg} \mathrm{kg}^{-1}$ ). The concentration of acyclic compounds explains $87.21 \%$ of the repellence of each extract on T. urticae (with a $99 \%$ confidence level).

Extraction with supercritical $\mathrm{CO}_{2}$ provided higher concentrations of sulphurated compounds, in comparison to the other techniques used in this study, resulting in a relatively clean product.

The results suggest that with extraction methods at high temperatures acyclic compounds are obtained and that processes at room temperature favor the formation of cyclic compounds in greater proportion. The extract obtained at room temperature using petroleum ether was more toxic than the other extracts (except that obtained with supercritical $\mathrm{CO}_{2}$ ) and while it did not show significant differences form the other treatments, it was observed that this extract had a stronger repellent effect.

\section{RESUMEN}

Comparación y caracterización de extractos de bulbos de ajo (Allium sativum L.) y su efecto en la mortalidad y repelencia de Tetranychus urticae Koch (Acari: Tetranychidae). Carlos Augusto Hincapié Ll. ${ }^{1}$, Gloria Eugenia López P. ${ }^{1}$, y Ricardo Torres Ch. ${ }^{2}$. Tetranychus urticae Koch es una plaga que causa grandes pérdidas económicas porque ataca un numeroso grupo de cultivos. Además, algunas poblaciones han desarrollado resistencia a acaricidas comerciales. Este trabajo compara diferentes extractos a partir de bulbos de ajo (Allium sativum L.) a través de su toxicidad y repelencia sobre $T$. urticae. Los extractos se obtuvieron usando como solventes $\mathrm{CO}_{2}$ en condiciones supercríticas (CSC), etanol y éter de petróleo usando el método Soxhlet y maceración y agua usando maceración. La técnica de fluidos supercríticos permite obtener extractos a temperaturas bajas usando altas presiones, evitando la degradación de los compuestos y permitiendo su separación del solvente al exponerlo a temperatura ambiente. El ácaro fue criado en laboratorio sobre plantas de fríjol (Phaseolus vulgaris L.) en el Campus Laureles de la Universidad Pontificia Bolivariana, Medellín, Colombia. La mortalidad fue evaluada colocando 10 ácaros en un disco de hoja de $P$. vulgaris de $3 \mathrm{~cm}$ de diámetro previamente sumergido en el extracto. Las concentraciones letales medias $\left(\mathrm{CL}_{50}\right)$ más bajas se obtuvieron con el método CSC $(8118,8 ; 5410,5 ; 2820,6$ $\mathrm{mg} \mathrm{kg}^{-1}$ a las 24,48 y $72 \mathrm{~h}$ respectivamente). Los extractos se caracterizaron usando cromatografía de gases-espectrometría de masas (GC/MS), obteniendo en el extracto CSC principalmente vinilditiínas $(63,11 \%)$, dialil disulfuro $(10,88 \%)$ y di-2-propenil trisulfuro $(10,4 \%)$. Se concluyó que la extracción con fluidos supercríticos permite obtener, a partir de bulbos de ajo, extractos con mayor concentración de compuestos biológicamente activos contra T. urticae, comparada con las otras técnicas usadas en este estudio.

Palabras clave: arañita roja bimaculada, extractos de plantas, efecto acaricida, Liliaceae. 


\section{ACKNOWLEDGEMENTS}

The authors wish to thank Rodrigo Vergara R., Fernando Cantor, José Ricardo Cure, the Faculty of Agricultural Sciences and the Instrumental
Analysis Laboratory of the School of Chemistry of the Universidad Nacional of Colombia, Medellín Campus, and the Integrated Center for Research Development (CIDI) of the Universidad Pontificia Bolivariana of Medellín.

\section{LITERATURE CITED}

Abbott, W. 1925. A method of computing the effectiveness of an insecticide. J. Econ. Entomol. 18:265-267.

Abu-Lafi, S., J. Dembicki, P. Goldshlag, L. Hanuš, and V. Dembitsky. 2004. The use of the 'Cryogenic' GC/MS and on-column injection for study of organosulfur compounds of the Allium sativum. J. Food Compos. Anal. 17:235-245.

Anazawa, Y., T. Tomita, Y. Aiki, T. Kozaki, and Y. Kono. 2003. Sequence of a cDNA encoding acetylcholinesterase from susceptible and resistant two-spotted spider mite, Tetranychus urticae. Insect Biochem. Mol. Biol. 33:509-514.

Aslan, I., H. Özbek, Ö. Çalmasur, and F. Sahin. 2004. Toxicity of essential oil vapors to two greenhouse pests, Tetranychus urticae Koch and Bemisia tabaci Genn. Ind. Crops Prod. 19:167-173.

Auger, J., I. Arnault, S. Diwo-Allain, M. Ravier, F. Molia, and M. Pettiti. 2004. Insecticidal and fungicidal potential of Allium substances as biofumigants. Agroindustria 3:5-8.

Bandyopadhyay, S., A. Roy, and S. Das. 2001. Binding of garlic (Allium sativum) leaf lectin to the gut receptors of homopteran pests is correlated to its insecticidal activity. Plant Sci. 161:1025-1033.

Banerjee, S., D. Hess, P. Majumder, D. Roy, and S. Das. 2004. The interactions of Allium sativum leaf agglutinin with a chaperonin group of unique receptor protein isolated from a bacterial endosymbiont of the mustard aphid. J. Biol. Chem. 279:23782-23789.

Beers, E.H., J.E. Dunley, and H. Riedl. 1998. Resistance to abamectin and reversion to susceptibility to fenbutatin oxide in spider-mite (Acari: Tetranychidae) populations in the Pacific-Northwest. J. Econ. Entomol. 9:352-360.

Bliss, C.I. 1934. The method of probits, a correction. Science 79:409-410.

Block, E. 1992. The organosulfur chemistry of the Genus Allium - Implications for the organic chemistry of sulfur. Angew. Chem. Int. Ed. Engl. 31:1135-1178.
Boyd, D.W., and D.R. Alverson. 2000. Repellency effects of garlic extracts on two spotted spider mite, Tetranychus urticae Koch. J. Entomol. Sci. 35:86-90.

Calvey, E., J. Matusik, K. White, J. Betz, E. Block, M. Littlejhon, et al. 1994. Off-Line supercritical fluid extraction of thiosulfinates from garlic and onion. J. Agric. Food Chem. 42:1335-1341.

Calvey, E.M., K.D. White, J.E. Matusik, D. Sha, and E. Block. 1998. Allium chemistry?: identification of organosulfur compounds in ramp (Allium tricoccum) homogenates. PhytoChem. 49(2):359-364.

Calvo-Gómez, O., J. Morales, and M. López. 2004. Solidphase microextraction-gas chromatographic-mass spectrometric analysis of garlic oil obtained by hydrodistillation. J. Chrom. A 1036:91-93.

Castiglioni, E., J. Vendramin, y M. Tamai. 2002. Evaluación del efecto tóxico de extractos acuosos y derivados de meliáceas sobre Tetranychus urticae Koch. (Acari: Tetranychidae). Agrociencia 6(2):75-82.

Chiam, W.Y., Y. Huang, S.X. Chen, and S.H. Ho. 1999. Toxic and antifeedant effects of allyl disulfide on Tribolium castaneum (Coleoptera: Tenebrionidae) and Sitophilus zeamais (Coleoptera: Curculionidae). J. Econ. Entomol. 92:239-245.

Chiasson, H., A. Belanger, N.J. Bostanian, C. Vincent, and A. Poliquin. 2001. Acaricidal properties of Artemisia absinthium and Tanacetum vulgare (Asteraceae) essential oils obtained by three methods of extraction. J. Econ. Entomol. 94:167-171.

Chiasson, H., N.J. Bostanian, and C. Vincent. 2004. Acaricidal properties of a Chenopodium-based botanical. J. Econ. Entomol. 97:1373-1377.

Chitwood, D.J. 2002. Phytochemical based strategies for nematode control. Annu. Rev. Phytopathol. 40:221-249. 
Choi, W., S. Lee, H. Park, and Y. Ahn. 2004. Toxicity of plant essential oils to Tetranychus urticae (Acari: Tetranychidae) and Phytoseiulus persimilis (Acari: Phytoseiidae). J. Econ. Entomol. 97:553-558.

Correa, L.G. 2004. Análisis de medidas repetidas. 41 p. Universidad Nacional de Colombia, Medellín, Colombia.

Finney, D.J. 1947. Probit analysis. 256 p. University Press, Cambridge, UK.

Garlic Barrier. 1999. Material safety data sheet. Available at http://www.garlicbarrier.com (Accessed 30 May 2005).

Han, M-K., S-I. Kim, and Y-J. Ahn. 2006. Insecticidal and antifeedant activities of medicinal plant extracts against Attagenus unicolor japonicus (Coleoptera: Dermestidae). J. Stored Prod. Res. 42:15-22.

Herron, H., and J. Rophail. 2002. The stability of tebufenpyrad resistance in two-spotted spider mite (Acari: Tetranychidae) under laboratory conditions. Exp. Appl. Acarol. 26(3-4):253-256.

Ho, S.H., L. Koh, Y. Ma, Y. Huang, and K.Y. Sim. 1996. The oil of garlic, Allium sativum L. (Amaryllidaceae), as a potential grain protectant against Tribolium castaneum (Herbst) and Sitophilus zeamais Motsch. Postharvest Biol. Technol. 9:41-48.

Huang, Y., S.X. Chen, and S.H. Ho. 2000. Bioactivities of methyl allyl disulfide and diallyl trisulfide from essential oil of garlic to two species of stored-product pests, Sitophilus zeamais (Coleoptera: Curculionidae) and Tribolium castaneum (Coleoptera: Tenebrionidae). J. Econ. Entomol. 93:537-543.

Iberl, B., G. Winkler, B. Muller, and K. Knobloch. 1990. Quantitative determination of allicin and alliin from garlic by HPLC. Planta Med. 56:320-326.

IDEAM. 1999. Cartas climatológicas, medias mensuales. Instituto de Hidrología, Meteorología y Estudios Ambientales. Bogotá, Colombia. Disponible en http://bart.ideam.gov.co/cliciu/mede/mede.htm (Leído el 27 de noviembre de 2006).

James, D.G., and T.S. Price. 2002. Fecundity in twospotted spider mite (Acari: Tetranychidae) is increased by direct and systemic exposure to imidacloprid. J. Econ. Entomol. 95:729-732.

Kim, H.K., J.R. Kim, and Y.J. Ahn. 2004a. Acaricidal activity of cinnamaldehyde and its congeners against Tyrophagus putrescentiae (Acari: Acaridae). J. Stored Prod. Res. 40:55-63.

Kim, E.H., H.K. Kim, D.H. Choi, and Y.J. Ahn. 2003. Acaricidal activity of clove bud oil compounds against Tyrophagus putrescentiae (Acari: Acaridae). Appl. Entomol. Zool. 38:261-266.
Kim, S.I., J.H. Yi, J.H. Tak, and Y.J. Ahn. 2004b. Acaricidal activity of plant essential oils against Dermanyssus gallinae (Acari: Dermanyssidae). Vet. Parasitol. 120:297-304.

Kimbaris, A.C., N.G. Siatis, D.J. Deferera, P.A. Tarantilis, C.S. Pappas, and M.G. Polissiou. 2006. Comparison of distillation and ultrasound-assisted extraction methods for the isolation of sensitive aroma compounds from garlic (Allium sativum). Ultrason. Sonochem. 13:54-60.

Knapp, M., and S.S. Kashenge. 2003. Effects of different neem formulations on the two-spotted spider mite, Tetranychus urticae Koch, on tomato (Lycopersicon esculentum Mill.) Insect Sci. Appl. 23:1-7.

Kuo, M., and C. Ho. 1992. Volatile constituents of the distilled oils of Welsh onions (Allium fistulosum L. var. Maichuon) and Scallions (Allium fistulosum L. var. Caespitosum). J. Agric. Food Sci. 40:111-117.

Kwon, J.H., and Y.J. Ahn. 2002a. Acaricidal activity of butylidenephthalide identified in Cnidium officinale rhizome against Dermatophagoides farinae and Dermatophagoides pteronyssinus (Acari: Pyroglyphidae). J. Agric. Food Chem. 50:4479-4483.

Kwon, J.H., and Y.J. Ahn. 2002b. Acaricidal activity of Cnidium officinale rhizome derived butylidenephthalide against Tyrophagus putrescentiae (Acari: Acaridae). Pest Manage. Sci. 59:119-123.

Landolt, P.J., R.W. Hofstetter, and L.L. Biddick. 1999. Plant essential oils as arrestants and repellents for neonate larvae of the codling moth (Lepidoptera: Tortricidae). Environ. Entomol. 28:954-960.

McClain, J. 2000. Processing with supercritical solvents. Chem. Eng. (New York) 107:72-79.

Migeon, A., and F. Dorkeld. 2007. Spider Mites Web: a comprehensive database for the Tetranychidae. Available at http://www.montpellier.inra.fr/CBGP/ spmweb (Accessed 27 April 2008).

National Institute for Standards and Technology. 1998. Libreria NIST98. Gaithersburg, Maryland, USA.

Park, B., S. Lee, W. Choi, C. Jeong, C. Song, and K. Cho. 2002. Insecticidal and acaricidal activity of piper-nonaline and piperoctadecalidine derived from dried fruits of Piper longum L. Crop Prot. 21:249-251.

Regnault-Roger, C., and A. Hamraoui. 1993. Efficiency of plants from the South of France used as traditional protectants of Phaseolus vulgaris L. against its bruchid Acanthoscelides obtectus (Say). J. Stored Prod. Res. 29:259-264. 
Ryback, M.E., E.M. Calvey, and J.M. Harnly. 2004. Quantitative determination of allicin in garlic: supercritical fluid extraction and standard addition of allicin. J. Agric. Food Chem. 52:682-687.

SAS Institute. 1999. SAS Online doc, version eight. Sas Institute, Cary, North Carolina, USA.

StatPoint, Inc. 1994. STATGRAPHICS PLUS V.5.0. Herndon, Virginia, USA.

Stumpf, N., C.P. Zebitz, W. Kraus, G.D. Moores, and R. Nauen. 2001. Resistance to organophosphates and biochemical genotyping of acetylcholinesterases in Tetranychus urticae (Acari: Tetranychidae). Pestic. Biochem. Physiol. 69:131-142.

Tsagkarakou, A., N. Pasteur, A. Cuany, C. Chevillon, and M. Navajas. 2002. Mechanisms of resistance to organophosphates in Tetranychus urticae (Acari: Tetranychidae) from Greece. Insect Biochem. Mol. Biol. 32:417-424.
Uesugi, R., K. Goka, and M.H. Osakabe. 2002. Genetic basis of resistances to chlorfenapyr and etoxazole in the two-spotted spider mite (Acari: Tetranychidae). J. Econ. Entomol. 95:1267-1274.

Yang, X., D.C. Margolies, K.Y. Zhu, and L.L. Buschman. 2001. Host plant-induced changes in detoxification enzymes and susceptibility to pesticides in the twospotted spider mite (Acari: Tetranychidae). J. Econ. Entomol. 94:381-387.

Yu, T.H., Ch. Wu, and Y.C. Liou. 1989. Volatile compounds from garlic. J. Agric. Food Sci. 37:725730 . 